\title{
Performative ethnography: difference and conviviality of everyday multiculturalism in Bellville (Cape Town)
}

\author{
Ala Rabiha Alhourani
}

\begin{abstract}
The paper explores the benefits of performative ethnography as a methodological intervention. The intervention discussed in this paper utilizes the persuasive power of aesthetics and performance to attain participation amongst a broad spectrum of research interlocutors and to challenge my own power and positionality in the fieldwork, whilst rendering me invisible as a participant observer. The performative ethnography discussed in this paper took place in the central business district (CBD) of Bellville, in the Cape Town area in South Africa, and consists of two performances, curated by the author, that took place at the same time. One is a painting performance through which Somali participants were invited to express their emotional experiences of living in Cape Town, and their memories, nostalgia and attachment to their land of origin. The painting performance revealed Somali diversity, multiple belongings and a politics of making cultural difference. The second performance was staged to overlap, in ways unanticipated by the participants, and consisted of a South African minstrel troupe walking through Bellville CBD, attaining a moment of conviviality through the unmaking of cultural difference. Beneath this methodological intervention is an exploration of the politics of difference and the conviviality of Bellville CBD's everyday multiculturalism.
\end{abstract}

\section{From informative to performative ethnography}

My inspiration for utilizing a performative ethnographic approach came from anthropologist Fabian's (1990) advice to ethnographers to move beyond the limitations of informative ethnography. ${ }^{1}$ Within Fabian's analysis, efforts to refine communication, approach and positivistic conceptions of research are always confined by a model wherein ethnographers ask questions of the other, who is expected to respond with information. For Fabian, this informative ethnographic model restricts research as it encourages 'asymmetrical' situations and relies on the assumption that individuals can simply call up and express information in discursive statements. Fabian argues that, in order to give sufficient consideration to important aspects of culture, ethnographers should adopt a performative approach and method. He explains:

Knowledge can be represented - made present - only through action, enactment, or performance ... The ethnographer's role, then, is no longer that of a questioner; he or she is 
but a provider of occasions, a catalyst in the weakest sense, and a producer (in analogy to a theatrical producer) in the strongest. (Fabian 1990, 6-7)

To move beyond this hierarchical positionality in fieldwork, Fabian advises the researcher to avoid acting as 'investigator' and rather to initiate a social event in fieldwork, an event around which research interlocutors can gather and engage. Fabian drew on Turner's (1982) theorization of performance as spectacular theatrical social drama. This theatrical function of performative ethnography corresponds with Boal's (1985) notion of 'invisible theatre' that involves the staging of a social drama in public spaces, without announcing its theatrical nature, by actors who do not reveal they are actors but who instead imitate and improvise the roles of real people with the aim to provoke and trigger the observing public to engage and debate social issues that are invisibly enacted. This dramatic/ethno- graphic strategy of provocation is related to ethnography's understandings of mutuality and 'shared revelation' (Fabian 1995). According to Fabian (1995, 47), ethnographic mutuality is 'the promise of nontrivial understanding that is produced by researcher and researched together'.

Inspired by Fabian's call, I initiated this performative ethnography as a methodological intervention in the space and time of Bellville central business district (CBD), so as to loosen the hierarchical power relationship between observer and observed, involve more participants in research observations and trigger their emotions to speak their minds through playful performance, instead of answering formal research questions. Through informative ethnography (participant observations and interviews), I learned about Somali ethnic and cultural diversity, the community's aesthetic formations and the ways in which they practice Islam. Being a Palestinian Muslim, and having lived in Cape Town for a decade, put me in the position of being a 'halfie' (Abu-Lughod 1991). From 2006 until 2010, I lived at the student residence at the University of the Western Cape (UWC), during which time I mainly did my shopping in Bellville CBD, as it was the closest market. Thus I was familiar with the cultural diversity and the presence of Somalis in Bellville CBD prior to the inclusion of the Somali community in my fieldwork. However, with the commencement of my ethnographic fieldwork, researching Somalis in Bellville CBD, I began regularly to attend prayer at al-Sunny Mosque and often had lunch at Somali restaurants. I sat for hours at various street corners, where I met and had coffee and chatted with many Somalis.

Despite this, it was particularly challenging for me to observe their identity politics of difference and belonging, and emotional experiences of living in Cape Town. The main challenge was that Somalis seemed to have negative perceptions of researchers; hence they were very hesitant to respond to my research inquiries. Although some of them were keen to be research interlocutors, some seemed to expect me to pay them money for their contributions to my research. I noticed that many of my research interlocutors had participated and been interviewed in previous research projects, and thus appeared to have prefigured answers to my research inquiries, often responding to my questions very 
formally and rationally, as if they were speaking through me and expected me to convey their responses to institutions or governmental departments.

To challenge my position as merely researcher in fieldwork, I volunteered for six months at the Bellville Education Centre in the CBD teaching basic English to Somali newcomers. This class consisted of one female and six male students and took place once a week for three hours. It included a break to attend the sunset prayer at the mosque. I always joined them at the mosque to avoid what Fabian explained as 'ethnographic misunderstanding' (1995) and as a way of maintaining their respect and expectations of me as a fellow Muslim. This was particularly important as they were aware that I am a Muslim and more importantly that I come from Palestine. Being an English teacher shifted the power relationship with my Somali students - instead of being a researcher seeking answers with no tangible reward or exchange for their assistance as research interlocutors, my role become one of a teacher providing assistance. I became known amongst the Somalis in Bellville CBD as a volunteer English teacher and not just a researcher. This voluntary participation allowed me access to what Erving Goffman (1959) identifies as 'back- stage' performance, where planning, preparation and mistakes could be observed that are often hidden and not seen by the public in 'front-stage' performance.

Moreover, I curated and staged two linked and overlapping social dramas to facilitate ethnographic encounters in fieldwork, in which performance is applied as a methodological intervention capable of sensorially persuading participants to reveal demotic vernacular politics of difference and to form a convivial collective. ${ }^{2}$ The outcome of this performative ethnography demonstrates cautiousness among Somalis around the public declaration of their diversity and feelings of fear about living in Cape Town. In comparison to this, during formal interviews, most research interlocutors appeared careful but eloquent in discussing their personal feelings of living in Cape Town. When they spoke about their origins, they often stressed their belonging to and membership of a cohesive Somali community. It was however through performative ethnography that the Somali participants entered into collective conversations in which they expressed clearly their shared feelings of fear and their cultural differences, multiple belongings and nostalgia and attachment to their homeland.

Across the two hours of this performative ethnography, the momentum of participants' excitement and emotional engagement rose to the extent that they appeared to become oblivious to the performances as a research methodology. Thus performative ethnography has the potential to move us beyond the limitations of an informative ethnography that often implicitly positions selected research interlocutors, obliging them to answer formal research questions in a context of hierarchical power relationships between observers and observed. Further still, this performative ethnography challenged my own power and positionality in the fieldwork and rendered me invisible while allowing me to be a participant observer. Crucially, this performative ethnography provides an example of how and why scholars need to engage performative ethnography whilst rethinking the 
hierarchical power relations that exist between researcher and research interlocutors that manifest within the centralized position of a researcher conducting fieldwork.

Moreover, the achievement of this performative ethnography is that it allowed me to observe the reactions and perceptions of Somali women and children. None of the Somali women I met agreed to converse with me on the basis that I am male and that this is forbidden according to their understanding of Islam. The few Somali women that I had a chance to speak to were always accompanied by relatives, either male or female. The number and kinds of participants who did get involved, and their statements and conversations thus transcended research observation beyond formal/informal conversations with selected interlocutors, who are mainly leaders or influential individuals in their respective communities. Through performative ethnography, more interlocutors became involved, were provoked and became exposed to each other, thus facilitating a revelation of their thoughts and feelings. Their collective engagement and debate brings to mind Tyler's (1986) definition of ethnography as a form of 'therapy', that is, a form of communication that has the power to restore, reassimilate and reintegrate the self in society, but also to redefine, revalorise and restructure the conduct of everyday life within a common-sense world.

The performative ethnography presented below consists of two curated (by the author) performances that took place at the same time on Sunday, 21 April 2013, from 12:00 until 14:00, in the CBD of Bellville, Cape Town. ${ }^{3}$ One is a painting performance through which Somali participants were invited to express their emotional experiences of living in Cape Town, and their memories, nostalgia and attachment to their land of origin. The painting performance revealed Somali diversity, multiple belongings and politics of making cultural difference. The second performance was staged to overlap, in ways unanticipated by the participants, and consisted of a South African minstrel troupe walking through Bellville CBD, attaining a moment of conviviality through the unmaking of cultural difference. 4

\section{A moment of conviviality: unmaking cultural difference}

On Sunday, 21 April 2013, 38 women, men and children from the Good Hope Entertainer minstrel troupe were picked up from the neighbourhood of Mitchells Plain and dropped at the south end of Durban Road in Bellville CBD, where they started a circular procession

through Bellville CBD. 5 The procession was led by a police car to manage the traffic, ensure accurate timing and provide a secure route. It was the first time a minstrel troupe marched in Bellville CBD, and therefore it was also the first time most of the immigrants in the area - many of whom live in Bellville CBD and do not attend cultural events in the centre of Cape Town - experienced such a performance Upon the first round through the CBD, spectators appeared amazed but attempted to avoid revealing their attention to the troupe (Figure 1). Initially a little tension emerged as many Somalis stepped out of al- Sunny Mosque. Some I had met formally or informally during my fieldwork and they approached me to state their disapproval of the minstrel performance, claiming that it did not accord with Islamic values. Abdulkadir Khalif, 
the chairperson of SASA, with whom I discussed the project beforehand, asked me to pack up the easels and to stop the minstrel procession, stating that 'Somalis do not like this kind of thing'. Khalif advised me in our early discussions not to conduct the project, but the presumed gains of such a performative ethnography encouraged me to take the risk and ignore his advice. That having been said, it was his advice that allowed me to prepare sincere and diplomatic responses to complaints aired by numerous individuals. Their main complaint was that the performance of the minstrel troupe did not accord with Islamic values, especially in terms of the dancing of women in the street. The other major complaint was that the minstrel performance disturbed their business.

As the minstrel troupe members continued their performance, they managed progressively to evoke a response: traders began to step out from their shops, more spectators (mainly men) gathered on both sides of the road, many stood on the balconies of shopping malls and women looked out from their windows. The ambiance of the minstrel songs eventually dislodged the anxiety and uncertainty of the crowd, and spectators began to get amicably involved by clapping and taking pictures with performers. Eventually it turned into a festive event and a moment of conviviality where immigrants and locals gathered and cheered around the entertaining Capetonian sound. As the minstrels made their fifth round, spectators became less resistant to the persuasive power of the minstrels' aesthetics and appeared to loosen their boundaries and collectively engage in a joyful mood of sociality. Some local spectators, those who appeared to be familiar with the minstrel songs, joined the procession. Even the police escorts became less serious and started to take pictures, clapping and chatting with the crowd. The head policeman, a white South African, appeared particularly pleased and thanked me whilst encouraging me to bring more local performances to Bellville CBD, stating, 'today the place is less hectic ... people are having a good time ... immigrants and locals mingling'. 


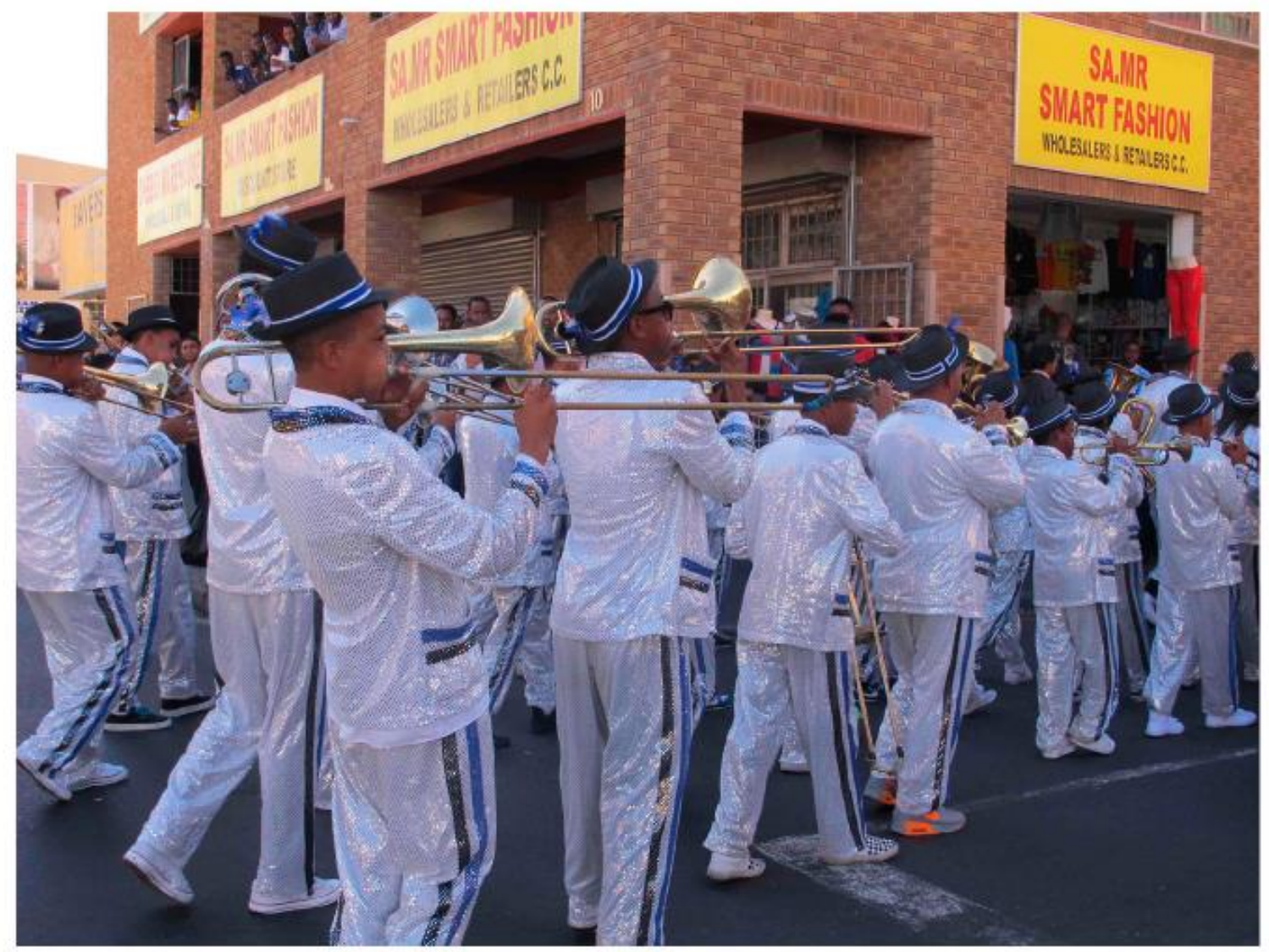

Figure 1. The minstrel performance, 21 April 2013, Bellville CBD (photo by the author).

What is significant here is the way and extent to which the persuasive power of the minstrels' sound threw a culturally diverse group into a common sensory experience of hearing a distinctly Capetonian sound. Hearing the sound of the minstrel songs fused with the typical soundscape of Bellville CBD drew upon the emotionality of listeners, placing them in jovial sociality, beyond the rational and institutionalized settings of cultural difference. The rhythmic sound of the minstrels' songs, their dance, humour and colourful body formations, embodied an 'aesthetic of persuasion' (Meyer 2010) that triggered an appealing emotional mood of conviviality. 6 This mood of conviviality threw the multicultural population of Bellville CBD into a jovial sociality, mutual interlocution and amicable interactions, with potential to foster modes of togetherness to transcend their difference.

\section{Making cultural difference/authenticating belonging}

As the sound of minstrel songs echoed within Bellville CBD, we set up 10 easels in the heart of Somali territory for participants to paint and write their experiences of South Africa and their attachment to their homeland. As we set up the easels, hung up white A3-sized sheets of paper and prepared the colours and brushes, a group of female Somali vendors started to complain that we were chasing away their potential customers. Gradually more Somali men and women started to gather, some curious and others frustrated about the easels. I encountered disapproval from many Somalis (some of whom were my research 
interlocutors), and although many seemed willing to participate, they were uneasy and hesitant to paint. To alleviate this, Roderick Sauls, a Capetonian scholar and artist, started to mix colours with water and drew a few lines to indicate to those around how easy it was to paint and use colours. It took approximately five minutes until Daea, who introduced herself as the chairperson of the Somali Women's Association in Cape Town, stepped in and grabbed the brush from Roderick, painting a smiling face and writing, 'I miss my mother and home'.

Following the lead of Daea and Sauls, Somalis eventually occupied the 10 easels, with several participants gathered around a particular easel (Figure 2). What is evident is that Somali engagement with the painting performance reveals identity difference and an intersection of multiple Somali 'belongings'; that is to say an intersection of belonging to cultural particularities, to an imagined community of Somalis living in Cape Town and to the transnational Muslim ummah. Some participants joyfully announced their nostalgia and attachment to Kenya or Ethiopia, where they lived before immigrating to South Africa.

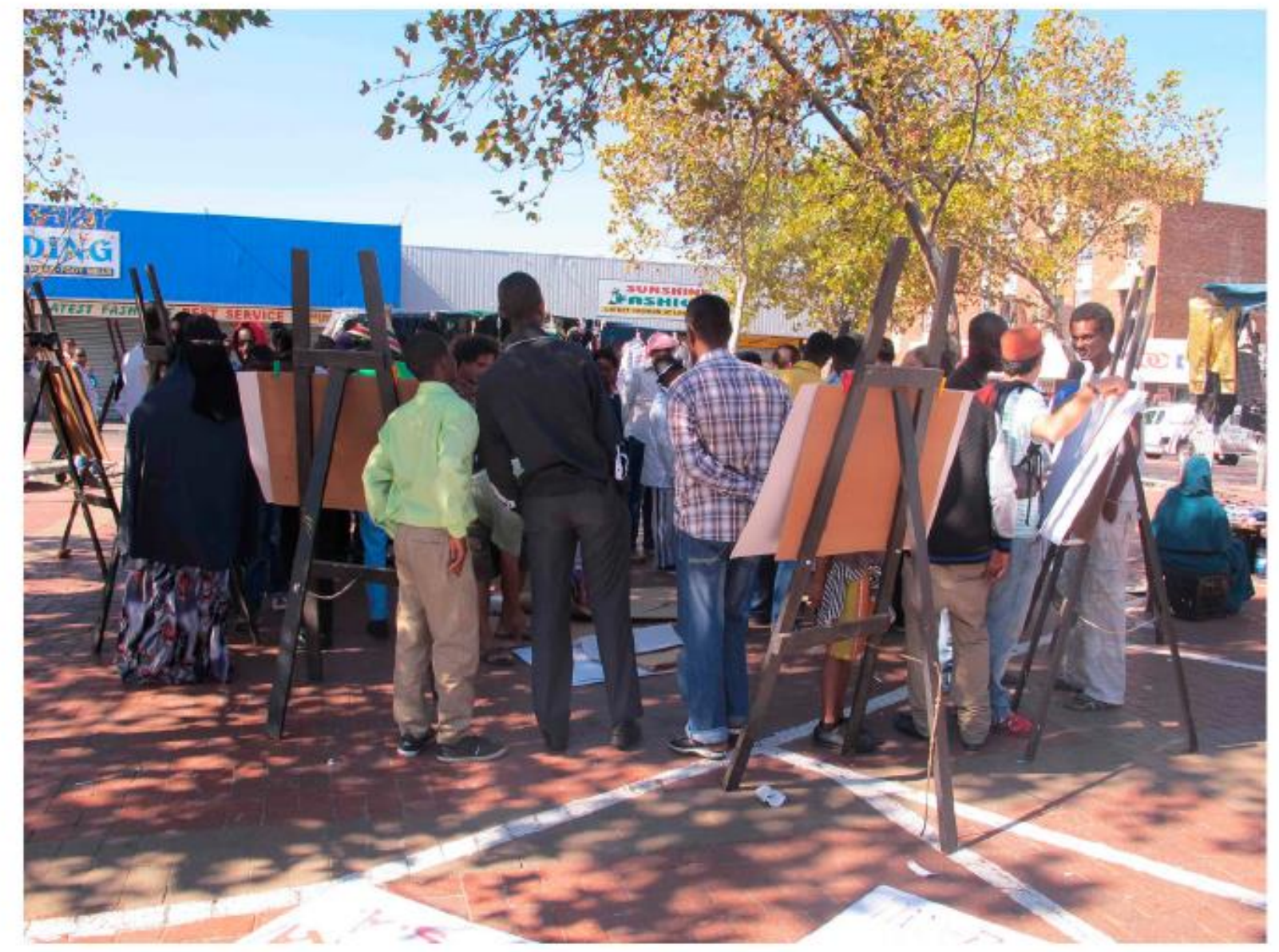

Figure 2. The painting performance, 21 April 2013, Bellville CBD (photo by the author). 
Their cultural differences were symbolically enacted through the variety of languages they used, which included English, Somali, Arabic, Swahili, Amharic and French. Here it is significant to note that the participants' expression of cultural difference and their attachment to places other than Somalia did not seem to undermine their sense of an imagined community of Somalis. While many expressed their love of Cape Town, South Africa and Nelson Mandela, one Somali man stepped towards me and said loudly, 'They are lying to you, we don't love South Africa'. He proceeded to grab a paintbrush to write in Arabic script, 'نالا ركبه جنبو يرفاقيا' (Ana bakrah Janoub Afriqia), which means I hate South Africa. His statement became the centre of attention for many participants and instigated discussion among them, resulting in the visibility of new emotions and expression on the white sheets of paper. Such expressions included, 'We choose the lesser of two evils between Somalia and South Africa', 'We love S.A., but we don't have bees [peace],' and 'We live in fear'. The individual participant's statement, 'Ana bakrah Janoub Afriqia' (I hate South Africa), and the subsequent conversation it evoked, appeared to form a shared feeling among the Somalis that 'unmade' their cultural difference, serving to bond them together as a distinct community within the multicultural society of Cape Town. Put differently, their expressions and conversations appeared to sustain a sense of difference on the one hand, and unmaking of difference on the other. What is interesting is that this performative ethnography strategically curated two interventions that are paradoxical in that it meant to destabilize one another; while the painting performance evoked expressions of difference, the minstrel performance involved multicultural participants in a collective convivial sensory experience. Each of both performances triggered conversations among multicultural population through which they mediated their sense of difference and sameness. During the minstrel performance break, most of the troupe performers, gathered around the painting performance witnessed and engaged with Somali expressions. One minstrel performer, a coloured South African woman, who left the troupe wrote, 'People love the Somalis, we are all people of God'. While Somali expressed a sense of difference, her statement embodied a sense of human sameness and intimacy.

What is most significant is that identity of difference and conviviality are mediated through performances and a related sensorial politics of authenticity and materialization. This performative vernacular identity politics of difference and conviviality runs parallel with the scholarly preoccupation towards how categories of difference are performed, reconfigured, become public and are embodied in everyday lived reality. ${ }^{7}$ Drawing on the growing scholarship on the politics of difference in post-colonial democratic African societies, such as South Africa, the following account explores Somalis' difference, their aesthetic formations of an imagined community, multiple layers of belongings. The discussion then proceeds to unpack the everyday politics of difference and conviviality of Bellville CBD's multiculturalism.

\section{Somalis in Bellville CBD 8}

Somalis in Bellville's CBD are a heterogeneous group and belong to different clans with diverse cultural backgrounds, statuses, ages, genders, classes and languages. ${ }^{9}$ Somalis' 
cultural diversity is manifested in their multilingual expertise, which reveals their various origins and cultural capital. Somalis are multilingual and most of them speak Somali and English fluently. The language skills of Somalis are influenced by their country of origin and mobility through various nations. ${ }^{10}$ The research interlocutors' answers showed how language had become for them a vehicle for mobility and exchange, and a signifier of personal history and multiple identities. An example of Somali multiple identities and belongings is seen in the practices of Somali research interlocutor Imam Mohammad Alawaal, who was born and raised in Ethiopia. The Imam speaks English, Arabic, Amharic and Somali and is an active member of the Somali and Ethiopian Muslim communities. Further to this, the Imam claims to be Arab and also regularly attends meetings of Arabs in Athlone. In the behaviour and approach of the Imam towards language, we see a coming together of lived realities (his places of origin and residence) and a sense of imagined connection to other cultural and linguistic groups (as signified by his identification with Arabs). Mohammad's multiple belongings and engagements are not an exception among Somalis in Cape Town. Rather, he is representative of Somali identity formations and involvement in 'simultaneity' and interrelated activities that can best be understood as unfolding within a framework of 'super-diversity' (Vertovec 2007). ${ }^{11}$

Despite the super-diversity of Somali identity formations and multiple belongings, it is vital to understand that various research interlocutors indicate a strong sense of an imagined community and shared collective identity of Somalis in Cape Town. What is of primary significance here is that the formation of the 'imagined community' of culturally diverse Somalis in Bellville CBD relies first and foremost on Islam. That having been said, the formation of collective identity and membership to the Somali community, or to be considered a 'true' Somali, is predicated on an individual's ability to speak the Somali language. ${ }^{12}$ In addition to these two factors, Somalis' shared feelings of fear amplified their sense of solidarity and form a collective identity that partially transcends their difference. (Alhourani 2015). ${ }^{13}$ Somali individuals claim multiple overlapping and intersecting belongings, which include their respective diverse cultural backgrounds and clan affiliations, an imagined Somali community in Cape Town, an imagined Muslim community in Cape Town, the transnational Somali community and the transnational Muslim community (Alhourani 2015). ${ }^{14}$ These senses of belonging can be understood as a tactical form of making and unmaking of difference performed by Somalis in their various positions within the multicultural context of post-apartheid Cape Town. ${ }^{15}$

Somalis constitute the largest Muslim community in Bellville CBD and, as their numbers constantly increase, they are gradually buying more properties in the area. ${ }^{16}$ Bellville is representative of the fact that, over the last decade, Somalis in South Africa have successfully created bases and 'homes away from home' for themselves. ${ }^{17}$ Somali infrastructure includes several mosques, Islamic schools, civic institution, restaurants, backpacker lodges, an Internet coffee shop and call centre and more than a hundred shops. ${ }^{18}$ The 
continuous rise in the Somali presence and inhabitation of Bellville CBD also explains why the area has become known as 'little Mogadishu' or 'little Somalia' (Tati 2008, 437).

\section{Bellville CBD}

On Saturday, 4 August 2012, during Ramadan, I went to Bellville CBD to film the space's gradual occupation from 05:00 to 10:00 in the morning, looking at the first arrivals and the social meanings of sounds, lights, smells and images embodied in the space There was nobody there yet; it was dark, rainy and somewhat frightening, with dogs barking in the distance. The first to appear were Somalis. From about 05:40 onwards, the sound of cart-pushers arriving from different corners, approaching the bus terminal, created an echo as the lights of the Somali bistro glared and the odour and steam of coffee and food swirled and more people arrived. These sounds, sights and smells engaged all the senses and revealed the aesthetic formations of Bellville CBD's public space. At 06:25, the rhythmic sound of azan emanated from the loudspeakers, pervading the space, calling Muslims to prayer. As the sun rose, the shops opened and vendors started mopping the floors on which they set up their stalls. It was the 16th day of Ramadan, during which Muslims increase their religious performance and the enactment of a religious self. Hence many shops played loud Quranic recitations that mediate a material audio-culture of Islam, marking the space and time of Bellville CBD with an audio-aesthetic of Islam, involving and implicating individuals (Muslim and non-Muslim) within the auditory range of its echoed sound. ${ }^{20}$ Such public performances of Muslim- ness signify an emergent aesthetics of public Islam and the Muslim public in Bellville CBD that is mostly formed and performed by Muslim immigrants, of whom (post-1990s) Somali refugees constitute the largest group. ${ }^{21}$

Drawing on Dwight Conquergood's argument that 'ethnography is an embodied practice; it is an intensely sensuous way of knowing' (1991, 180), this paper presents a sensory ethnography (Pink 2009) that relies on 'participant sensation' and observation (Howes 2006). Walking in and through Bellville CBD was an act of 'appropriation' (De Certeau 1998, 97), of building a relationship and familiarity with different spaces to capture its temporalities. I visited Bellville regularly and each time my feelings shifted as I moved from space to space in Bellville CBD. I usually had a feeling of fear and discomfort in the space of the bus terminus that is mainly occupied by young West African immigrants, who once offered me drugs and often gazed at my belongings. Police located on the corner advised me to be cautious when I used my camera there. On the other side of the road (Charl Malan Street), as one enters Middestad Mall, the commercial signage, including King Pie, Fish, Jet, Markhams and ShopRite, marks the space as South African territory, crowded with local South Africans whose phonetic sounds are mainly either Afrikaans or isiXhosa. At the other entrance/exit of Middestad Mall one approaches Somali territory.

Bellville is a space of intense temporality and mobility, with a constant flow of locals and immigrants that brings about hybrid cultural complexity (Hannerz 1992). The cultural 
diversity of Bellville CBD is publicly enacted through different foods, people's body formations and people's phonetic sounds and music. The complex sonic composition of the overlapping sounds of various music and Quranic recitations is mixed, indeed interpreted in English, Afrikaans, Swahili, Somali, Amharic and many West African languages. This brings to mind sociologist Thibaud's $(2003,331)$ statement that 'the city is also to be heard and not to be only seen'.

Although cultural diversity in Bellville CBD is publicly enacted, the continuous interactions of people there are not determined by a single factor, such as ethnicity, religion, nationality, race, gender or age; instead, the social relations and interactions involve variable shared factors, which make Bellville CBD a space of super-diversity (Vertovec 2007). Ighsaan Nor Alden, the chairperson of the Ethiopian Muslim community in Bellville, pre- ferred to meet me for an interview at the Pakistani restaurant, where I also met Ahmad, a Somali businessman who previously worked and lived in Saudi Arabia and who therefore said he likes curry and Pakistani food more than Somali food. Before conducting my interview, I had to wait for Agshaan to follow up on a previous conversation with Mohammad Abu Baker Kadire, the owner of the restaurant. Their conversation was marked by both pensive and humorous moods that came through the presentation of their shared interests, experiences and memories of living in Bellville CBD.

This shard sensory experience of living together reveal an 'obvious sense of human sameness' (Gilroy 2006, 6), that transcend their difference and renders Bellville CBD as a space of convivial multiculturalism. ${ }^{22}$ The conviviality of Bellville CBD's everyday multiculturalism indicates that categories of cultural, social and religious difference are contextual, temporal and performative in the sense that it is 'real only to the extent that it is performed' (Butler 1988, 527). This calls attention to ways in which identity politics of difference intersect, diverge and come together with the performance of convivial collective identity.

\section{Notes}

1. Fabian's notion of performative ethnography comes from his own ethnographic experience with theatre performance and actors in the Shaba province of Zaire, and in his work he has explored the ways in which the performance of le pouvoir se mange entire (power is eaten whole) was created, rehearsed and performed. His approach was triggered by the limitations he perceived in Hymes' $(1968,1971$ ) 'ethnography of speaking'. Although Hymes's ethno- graphic model includes communicative dialogical conversation, it still implies a hierarchical power relation between observer and observed.

2. The integral relationship among performance, power, the senses and politics of difference is something vital to the work of anthropologists and the editors of this special issue, Becker and Lentz $(2013,1)$, whose work develops an understanding of performance as a strategic 'embo- died symbolic enactment' and as a process of creation and enactment $(2013,6)$. Kelly Askew's work makes clear the vital role of performance in the creation of social reality. She explains this clearly by saying that performance is always 'contingent, 
emergent, undetermined, and susceptible to unrehearsed actions' (2002, 14-15). Thus, 'performance is a process engaging "per- formers" and "audience" and 'does not mirror social reality or merely reflect upon it, it actively creates it' (2002, 14-15). Here, Askew's work channels the notion of performance as a creation that is championed in the work of multiple researchers. This is particularly the case in the work of Turner (1982), who argues that performances are 'making, not faking' social facts, and Fabian (1990, 9), who finds that 'a performance does not "express" something in need of being brought to the surface, or to the outside; nor does it simply enact pre-existing text. Performance is the text in the moment of its actualization'. Similarly, this approach echoes the work of Ebron $(2002,1)$, who argues that 'performance and the politics of culture-making come together to inform one another's ability to exist'.

3. Initially the project consisted of three artistic performances: first, graffiti painting of the phrase 'Feel Home' in several languages (English, Afrikaans, isiXhosa, Swahili, Somali, Arabic, Amharic and French among others), which attempted to symbolize recognition and celebration of Bellville's multiculturalism; second, setting up 10 easels for participants to draw/paint their feelings and, third, a minstrel troupe that marched in and through Bellville CBD. I attended three meetings with the Bellville City Council in which I explained my position as a student and the academic purposes and gains of performative ethnography, but also proposed that such an art project has the potential to provide a missing link between locals and immigrants and might help integrate immigrants into the larger society of Bellville. After obtaining consent from various shop owners in Bellville $\mathrm{CBD}$, as was requested by the Council, I was given permission to conduct the latter two performances and not the graffiti, because they claimed that graffiti did not accord with the long strategic planning of the city of Bellville and, as a member of the Council stated, 'graffiti is underground art for gangsters'. The permission entailed that the project must only take place on a Sunday, which is less busy and sees less traffic, since most of the shops in Bellville CBD are closed.

4. The event was filmed. The link for the minstrel performance is https://vimeo.com/70070142. The link for the painting performance is https://vimeo.com/70353008

5. The minstrel troupe, who are locally referred to as 'Klopse,' are Capetonian performers. They are mainly known for their participation in the New Year Minstrel Carnival event that takes place every year on January 2 - a day when coloured slaves were traditionally granted a one-day holiday. The Carnival first emerged in 1823, and since then it has become one of the most celebrated events among the working class of the coloured community in Cape Town. It serves as a symbolic cultural representation of the coloured community at the local and national levels (Jeppie 1990; Baxter 2001). In 2012, I drummed with Good Hope Entertainer in their procession at the New Year Minstrel Carnival. Mitchells Plain is one of the largest townships in South Africa, located approximately 35 kilometres from the centre of Cape Town. With a population of about 300,000 people, most of whom are coloured, Mitch- ells Plain was created in the early 1970 by the apartheid government to relocate those who were forcefully evicted from their homes in areas designated for whites (Arendse 2010). 
6. Employed in the contexts of heritage formations politics of authentication Meyer's concept of an 'aesthetic of persuasion' evokes the sensorial affect of aesthetics in the politics of authenticating identity and belonging. In this regard, this paper frames aesthetics through an Aristotelian view of aesthesis, in other words 'our total sensory experience of the world and our sensitive knowledge of it' (Meyer and Verrips 2008, 21), rather than a Kantian notion of 'pure' beauty confined to the sphere of the arts.

7. The formation of the modern nation-state in various post-colonial African societies foster a resurgence of identity politics and difference which in turn become amplified by rise of neo- liberalism, globalisation and multiculturalism (Comaroff and Comaroff 2005, 2009; Becker 2010; Schulz 2012). Relevant to this ethnography is How We See Our Culture (2015) by anthropologist Heike Becker, which locates its focus beyond the politics of cultural difference at the level of institutional mechanisms to investigate demotic vernacular forms of the politics of cultural difference. This was achieved in Becker's work (2015) through a method of performative ethnography wherein she gave cameras to research interlocutors, asking them to picture what they perceived to be their culture. Through this method, Becker (2010) drew attention to the troubling connection between the politics of difference, belonging and exclusion in the context of post-apartheid multiculturalism.

8. Somali appearance in Bellville CBD is a post-apartheid phenomena. The experience of migration relayed to me by research interlocutors reflects the three main phases of Somali migration to Cape Town. The first wave occurred in the early 1990s, the second between 1995 and 2000 and the third in 2006, after Ethiopia invaded Somalia. Somali migration centred mainly on African countries but also reached Europe and the United States (Farah 2000). The largest camp of Somali refugees today is at Dadaab, located in north eastern Kenya, which houses 387,077 Somali refugees, with a monthly influx of approximately 9000 new arrivals (Lindley 2011). Southern Africa has registered an increasing number of Somali immigrants, many of whom consider South Africa their main destination. This is because immigrants to South Africa can gain refugee status, which allows them more freedom of movement and business opportunities, in contrast to being located in an enclosed camp in Kenya or Ethiopia (Sadouni 2009; cf. Steinberg 2014). None of my research interlocutors migrated directly from Somalia to Bellville CBD. Rather, each has his or her own story of crossing borders and settling temporally in Somali enclaves in Nairobi, Addis Ababa, Dar es Salaam or Maputo, where they sought help from clan members to make a living or to continue their journey to Johannesburg and then to Bellville.

9. Historically, Somalis belong to various clans, among which are the Dir, Isaaq, Darod, Hawiye, Digil, Mirifle and Rahanweyn, each of which is divided into sub-clans. Ahmed and Green (2007) argue against an understanding of Somalis as a culturally homogenous community, rather noting that Somalis 'have distinctively different cultural, linguistic and social structures'. Anthropologist Lewis (1994) argues that the Somalis' sense of collective identity has been historically challenged by their strong segmentary clan affiliations. Moreover, Somalis' different colonial experiences (British, Italian, Ethiopian and French) entail differences in colonial administrative order, language and culture. As in the case of other African societies, colonialism rendered Somalis as tribal subjects governed by a different legal system and ethnically distinct political authority. This argument was 
made clear by Mamdani (1996, 2004), who explores the ways in which European colonial politics strategically fragmented African societies along ethnic lines through unequal distribution of power and resources, that favour particular ethnic groups over others, exaggerating cultural difference and antagonism among various colonialized ethnic groups. This colonial strategy of making cultural difference along clan affiliations become embodied social categories that continue to undermine Somali collective constellations, social interactions and political and economic commitments (Samatar 1992). Throughout the colonial period, Somalia was divided into two separate colonial territories: Somaliland in the north, colonialized by the British, and Somalia in the south, colonised by the Italians. Both of these territories are inhabited by multiple clans. Contrary to this emphasis on Somalis' divisive difference, Samatar (1988) notes that formations of Somali collective identity and shared values date to the pre-colonial era. He argues that Somalis' ideology of kinship and social relations is not merely based on clan blood ties but rather is highly marked by the culture of Xeer, and Islamic values. Samatar (1988) describes Xeer as precolonial socially con- structed values that formed Somali social bonds around 'a pan-Somali code of conduct' that embodied common wisdom and values shared across various clans and genealogical groups. Other shared values among Somalis were formed when they embraced Islam in the eighth century.

10. Somalis who were born or lived in Kenya speak Swahili, whilst those who were born or lived in Ethiopia speak Amharic, while those who were born in Eritrea or Djibouti speak French. Some Somalis I met learned to read Arabic in Somalia, and those who worked or studied in Arab countries can speak Arabic.

11. Steven Vertovec coined the term 'super-diversity' to describe the increase and complexity of the variable factors involved in identity formation and diversification of diversity, against the static categorization of cultural difference in multiculturalism. In Vertovec's $(2007,1025)$ words, 'The interplay of these factors is what is meant here, in summary fashion, by the notion of super-diversity.'

12. What is significant is that Islam and the Somali language have shaped Somali collective identity and shared social values since the pre-colonial era, and have continued to play a crucial role in the formation of Somali collective identity and a shared cultural style during the Somali nation building project and in various diasporic contexts (Samatar 1992).

13. This culture of solidarity among Somali immigrants living in Cape Town and in South Africa at large has led to the establishment of a business network through which they provide support for newcomer Somalis. Upon arrival in South Africa, Somalis often seek help from members of their clan to work as shopkeepers, street traders or hawkers (Jinnah 2010; Steinberg 2014). Although this diasporic culture of solidarity plays a big role in the formation of collective identity and imagined community, it remains highly marked by clan affiliations, which so often challenge the construction and representation of cohesive Somali communities in the diaspora (Hopkins 2006) or in Somalia itself (Lewis 1994).

14. Somali transnationalism is amplified by access to, and use of, evolving communication and media technologies, which stretches to include Somalis from all over the world. These technological devices and outlets provide a medium for global engagement employed by Somalis to share their aesthetic forms and various experiences in different localities. On the one hand, this serves to form the imagination of a 
transnational Somali community, whilst on the other providing a mechanism that facilitates sociocultural, economic and political transformations across transnational borders (Vertovec 2004). Moreover, the construction of Somali transnational community is manifested through economic frameworks and systems. An example of this is the money transfer system known by its Arabic name Hawala.

Through Hawala one can transfer money from any rural or urban area to the rest of the world (Lindley 2009).

15. This fluid sense of belonging is described by Landau and Freemantle (2010, 381) as 'tactical cosmopolitanism', in a sense that such multiple and shifting ethnic, national and transnational senses of belonging mark an immigrant's reactive strategy 'to live outside of belonging while claiming the benefits of it'.

16. The number of Somalis in South Africa is estimated to be between 27,000 and 40,000 (Jinnah 2010). Daheer, the chairperson of the Older Council of the Somali Community in Western Cape, estimated that the number of Somalis in Cape Town to be between 15,000 and 17,000, and the Somali residents in Bellville CBD to number between 6000 and 7000. This population in Bellville CBD reaches its peak each Sunday, when Somalis come from surround- ing townships to eat at Somali restaurants and socialise with their Somali relatives and friends. In 2008, as a consequence of xenophobic attacks by South Africans, many Somalis moved from townships to live in Bellville CBD, where they sought and found community protection.

17. This is evident not only in Bellville CBD (Alhourani 2015) but also in the suburb of Mayfair in Johannesburg (see Jinnah 2010).

18. The Muslim population in Bellville CBD consists of South Africans and Somalis, alongside other immigrants, including Ethiopians, Pakistanis, Arabs and West Africans.

19. You can watch the film at https://vimeo.com/55197076

20. Here, the sound of the Arabic language is seen as an 'aesthetically coded sentiment' that constitutes an 'ideology of emotion' (Feld 1982, 217) and as Collingwood argues 'is an imaginative activity whose function is to express emotion' ([1958] 1981, 224). The aesthetic sound of the Arabic language thus enacts a sensorial embodiment of Muslim-ness that is perceived by Muslims as having a shared social meaning, which metaphorically manifests in sound. Here I draw on Steven Feld's (1982) ethnography of sound among the Kaluli people of Papua New Guinea, in which he explores the expressive modalities of weeping, poetics and songs of the Kaluli people, which are communicated through sound as an embodiment of deeply felt sentiment and a structured cultural system.

21. The Muslim population in Bellville CBD consists of South Africans and Somalis, alongside other immigrants, including Ethiopians, Pakistanis, Arabs and West Africans.

22. Here, I perceive conviviality as a conceptual and analytical frame that moves beyond fixations of assumed categorizations of difference of multiculturalism and cosmopolitanism, but instead reveal human mode of living together (Gilroy 2004; Nowicka and Vertovec 2013). Within this context, conviviality transcends its literal English meaning of joyful, festive and a good time, embracing Overing and Passes' (2000) argument concerning Amazonian indigen- ous conviviality that is 'the ethical, the aesthetic, emotion talk, styles of relating and speaking' and of living together a shared life that not only relies on love, peace and goodness but also 'is one that recognizes a continuous interplay 
between the constructive and destructive emotions and reasonings'. Illich's 'Tool for Conviviality' (1973) proposes several tools to escape from the power-centred industrial regime to post-industrial 'convivial society' that enjoys individual autonomy, freedom and the agency of its members.

\section{Disclosure statement}

No potential conflict of interest was reported by the author.

\section{Funding}

This work was supported by South Africa Netherlands Research Programme for Alternative in Development (SANPAD) and the Max Plank Institute for the Study of Religion and Ethnic Diversity

(MPI-MMG). 


\section{References}

Abu-Lughod, Lila. 1991. "Writing Against Culture." In Recapturing Anthropology. Working in the Present, edited by R. G. Fox, 137-162. Santa Fe: School of American Research Press.

Ahmed, I. Ismail, and Reginald Herbold Green. 2007. "The Heritage of war and state Collapse in Somalia and Somailand: Local-level Effects, External Interventions and Reconstruction." Third World Quarterly 20 (1): 113-127. doi:0143-6597/99/01011313.

Alhourani, Rabiha Ala. 2015. "Aesthetics of Muslim Public and Community Formations in Cape Town: Observations of an anthropologist." Anthropology Southern Africa 38 (12): 103-119. http://dx.doi. org/10.1080/23323256.2015.1052825.

Arendse, Kelly. 2010. "Altering Perceptions Reconnecting people to Place and invoking spirit of Place." Master thesis, Johannesburg University of the Witwatersrand.

Askew, Kelly. 2002. Performing the Nation: Swahili Music and Cultural Politics in Tanzania. Chicago, IL: University of Chicago Press.

Baxter, Lisa. 2001. "Continuity and Change in Cape Town's Coon Carnival: The 1960s and 1970s." African Studies 60 (1): 87-105. http://dx.doi.org/10.1080/00020180120063638.

Becker, Heike. 2010. "Introduction to Anthropology Southern Africa special issues on Engaging Difference: Perspective on Belonging and Exclusion in Contemporary Southern and East Africa." Anthropology Southern Africa 33 (3\&4): 75-80. http://dx.doi.org/10.1080/23323256.2010.11499995. Becker, Heike. 2015. "How We See Our Culture: Photographic self-Representations from The Cape Flats, South Africa." Visual Anthropology 28: 373-397. http://dx.doi.org/10.1080/08949468.2015.1085791.

Becker, Heike, and Carola Lentz. 2013. "The Politics and Aesthetic of Commemoration; National Day in Southern Africa." Anthropology Southern Africa 36 (1\&2): 1-10. http://dx.doi.org/10.1080/ 02580144.2013.10887019.

Boal, Augusto. 1985. Theatre of the Oppressed. New York, NY: Theatre Communication Group. Butler, Judith. 1988. "Performative Acts and Gender Constitution: An Essay in Phenomenology and Feminist Theory." Theatre Journal 40 (4): 519-531. doi:10.2307/3207893.

Collingwood, Robin George. [1958] 1981. The Principles of Art. London: Oxford University Press. Comaroff, John, and Jean Comaroff. 2005. "Reflection on Liberalism, Policulturalism \& ID-ology:

Citizenship \& Difference in South Africa." In Limits to Liberation after Apartheid: Citizenship, Governance \& Culture, edited by S. L. Robins, 173-189. London: James Currey.

Comaroff, John, and Jean Comaroff. 2009. Ethnicity, INC. Scottsville: University of Kwazulu Natal Press. Conquergood, Dwight. 1991. "Rethinking Ethnography: Towards a Critical Cultural Politics." Communications Monographs 58 (2): 179-194.

De Certeau, Michel. 1998. The Practice of Everyday Life. Oakland, CA: University of California Press. Ebron, Paulla. 2002. Performing Africa. Princeton, NJ: Princeton University Press. 
Fabian, Johannes. 1990. Power and Performance: Ethnographic Explorations through Proverbial Wisdom and Theatre in Shaba, Zaire. Madison: University of Wisconsin Press.

Fabian, Johannes. 1995. "Ethnographic Misunderstanding and The Perils of Context." American Anthropologist 97 (1): 41-50.10.1525/aa.1995-97.1.02a0oo8o

Farah, Nuruddin. 2000. Yesterday, Tomorrow: Voices from Somali Diaspora. London: Cassell.

Feld, Steven. 1982. Sound and Sentiment: Birds, Weeping, Poetics, and Song in Kaluli Expression. 2nd ed. Philadelphia: University of Pennsylvania Press.

Gilroy, Paul. 2004. After Empire: Melancholia or Convivial Culture? Abingdon: Routledge.

Gilroy, Paul. 2006. Colonial Crime and convivial Culture. Rethinking Nordic Colonialism. Video letter at "Debating Independence: Autonomy or Voluntary Colonialism", Greenland.

Goffman, Erving. 1959. The Presentation of Self in Everyday Life. New York, NY: Doubleday.

Hannerz, Ulf. 1992. Cultural Complexity: Studies in the Social Organization of Meaning. New York, NY: Columbia University Press.

Hopkins, Gail. 2006. "Somali Community Organizations in London and Toronto: Collaboration and Effectiveness." Journal of Refugee Studies 19 (3): 361-380. doi:10.1093/jrs/felo13.

Howes, David. 2006. "Charting the Sensorial Revolution." Senses \& Society, 1 (1): 113-128. Hymes, Dell. 1968. "The Ethnography of Speaking." In Reading in the Sociology of Language, edited by Joshua A. Fishman, 99-138. Mouton Publisher.

Hymes, Dell. 1971. "Sociolinguistics and the Ethnography of speaking." In Social Anthropology and Language, edited by Edwin Ardener, 47-94. London: Routledge.

Illich, Ivan. 1973. Tools for Conviviality. Glasgow: Fontana.

Jeppie, Shamil. 1990. "The Class, Colour and Gender of Carnival: Aspects of a Cultural Form in Inner Cape Town, c.1939-c.1959." Paper presented at the "Structure and Experience in the Making of Apartheid". Conference, History Workshop, University of the Witwatersrand, Johannesburg, February 6-10. http://hdl.handle.net/10539/7826.

Jinnah, Zaheera. 2010. "Making Home in a Hostile Land: Understanding Somali Identity, Integration, Livelihood and Risk in Johannesburg." Journal of Sociology and Anthropology 1 (1-2): 91-99.

Landau, Loren B, and Iriann Freemantle. 2010. "Tactical Cosmopolitanism and Idioms of Belonging: Insetion and Self-Exclusion in Johannesburg." Journal of Ethnic and Migration Studies 36 (3): 375- 390. http://dx.doi.org/10.1080/13691830903494901

Lewis, Ioan Myddin. 1994. Blood and Bone: The Call of Kinship in Somali Society. Lawrenceville, NJ: Red Sea Press.

Lindley, Anna. 2009. "Between 'Dirty Money' and 'Development Capital': Somali Money Transfer infra- structure Under Global Scrutiny.” African Affairs 108 (433): 519-539. doi:10.1093/afraf/adpo46.

Lindley, Anna. 2011. "Between a Protracted and a Crisis Situation: Policy Responses to Somali Refugees in Kenya.” Refugee Survey Quarterly 1-36. doi:10.1093/rsq/hdro13 
Mamdani, Mahmood. 1996. Citizen and Subject: Contemporary Africa and the Legacy of Late Colonialism. Princeton, NJ: Princeton University Press.

Mamdani, Mahmood. 2004. "Race and Ethnicity as Political Identity in the African Context." In Keywords: Identity, edited by Nadia Tazi, 3-23. New York, NY: Other Press.

Meyer, Birgit, and Jojada Verrips. 2008. “Aesthetic." In Key Word in Religion, Media and Culture, edited by David, Morgan, 20-31. New York, NY: Routledge.

Meyer, Birgit. 2010. "Aesthetics of Persuasion." South Atlantic Quarterly 109 (4): 741-763. doi:10.1215/00382876-2010-015.

Nowicka, Magdalena, and Steven Vertovec. 2013. "Introduction. Comparing convivialities: Dreams and Realities of Living-With-Difference." European Journal of Cultural Studies 17 (4): 341-356. doi:10.1177/1367549413510414.

Overing, Joanna, and Alan Passes. 2000. "Introduction: Conviviality and the Opening up of Amazonian Anthropology." In The Anthropology of Love and Anger; The Aesthetic of Conviviality in Native Amazonia, edited by J. Overing and A. Passes, 131. London: Routledge.

Pink, Sarah. 2009. Doing Sensory Ethnography. London: SAGE.

Sadouni, Samadia. 2009. "God is not Unemployed: Journeys of Somali Refugees in Johannesburg." African Studies $68 \quad$ (2): $\quad 235-249$. http://dx.doi.org/10.1080/00020180903109615

Samatar, Ahmed. 1988. Socialist Somalia: Rhetoric and Reality. London: Institute for African Alternative.

Samatar, Abdi Ismail. 1992. "Destruction of State and Society in Somalia: beyond the Tribal Convention." The Journal of Modern African Studies 30 (4): 625-641. DOI: https://doi.org/10. 1017/So022278Xo0011083

Schulz, Dorothea E. 2012. Muslims and New Media in West Africa: Pathways to God. Bloomington: Indiana University Press.

Steinberg, Jonny. 2014. A Man of Good Hope. Johannesburg: Jonathan Ball.

Tati, Gabriel. 2008. "The Immigration Issues in the Post-Apartheid South Africa: Discourses, Policies and Social Repercussions." Space Populations Societies 3: 423440.

Thibaud, Jean Paul. 2003. "The Sonic Composition of the City." In The Auditory Culture Reader, edited by Bull Michael and Back Les, 329-342. Oxford: Berg.

Turner, Victor. 1982. From Ritual to Theatre: The Human Seriousness of Play. New York, NY: Performing Arts Journal Publications.

Tyler, Stephen. 1986. "Post-Modern Ethnography." In Writing Culture. The Poetics and Politics of Ethnography, edited by James Clifford and Marcus E George, 122-140. Oakland, CA: University of California Press.

Vertovec, Steven. 2004. "Migrant Transnationalism and Mode of Transformation." International Migration Review 38 (3): 970-1001. doi:10.1111/j.17477379.2004.tboo226.x

Vertovec, Steven. 2007. "Super-Diversity and its Implications." Ethnic and Racial Studies 30 (6): 1024- 1054. http://dx.doi.org/10.1080/01419870701599465 


\section{Audio and Visual Media}

Alhourani, Ala Rabiha. 2013. Aesthetic Formations of Super-Diversity. Vimeo. https://vimeo.com/ 55197076.

Alhourani, Ala Rabiha. 2013. Performative Ethnography: Painting Performance. Vimeo. https://vimeo. com/70353008.

Alhourani, Ala Rabiha. 2013. Performative Ethnography: Minstrel Performance. Vimeo. https://vimeo.com/70070142. 